\title{
Review Article \\ Critical Review on Wild-Edible Fruit Species in Ethiopia
}

\author{
Alebel Melaku $\mathbb{D}^{1}$ and Mohammed Ahmed Ebrahim ${ }^{2}$ \\ ${ }^{1}$ College of Agriculture and Natural Resource Debre Markos University, P. O. Box 269, Debre Markos, Ethiopia \\ ${ }^{2}$ College of Agriculture and Natural Resource, Mekdela Amba University, Tulu Awuliya, Wollo, Ethiopia
}

Correspondence should be addressed to Alebel Melaku; alebel_melaku@dmu.edu.et

Received 19 April 2021; Revised 18 July 2021; Accepted 11 September 2021; Published 23 September 2021

Academic Editor: Anna Źróbek-Sokolnik

Copyright (C) 2021 Alebel Melaku and Mohammed Ahmed Ebrahim. This is an open access article distributed under the Creative Commons Attribution License, which permits unrestricted use, distribution, and reproduction in any medium, provided the original work is properly cited.

\begin{abstract}
Wild edible fruit species are commonly consumed and utilized in different parts of Ethiopia for staple food, filling seasonal food shortages, emergency food during a famine, and household income generation. There is a pressing need for domestication and improvement of some wild edible fruits for increased production, diversifying income for small-scale farmers, and conservation of the diminishing wild edible fruit resources. A total of 37 widely utilized and marketed wild edible fruit species falling into 23 families were recognized as of used in different parts of the country. Of which, 26 species are identified as available in local markets in different parts of the country. Ziziphus spina-christi, Syzygium guineense, Balanites aegyptiaca, and other nine species were identified as a priority wild edible fruit species from available information based on utilization extent, preference ranking by farmers, product marketability, and conservation needs for the species. There exists a lack of scientifically planned genetic variation evaluation, superior variety selection, genetic improvement, and seedling production initiatives for indigenous wild edible fruit species in Ethiopia. All of the 37 widely utilized and marketed wild fruit species have not developed to their full potential in terms of quality, production scale, and market in the country. Identifying and selecting priority species, strengthening botanical information, germplasm collection and improvement, production and processing technologies, increasing the supply of improved planting materials, and promoting on-farm cultivation of wild edible fruit-based agroforestry systems were identified as key future strategies for domestication and wider cultivation of wild edible fruit species.
\end{abstract}

\section{Introduction}

Continuous degradation of natural ecosystems by an everincreasing demand for land resources has resulted in food insecurity among rural communities [1]. Diversifying production and consumption of underutilized species contribute to improve livelihoods (i.e., food security, incime generation, and health) and provide other ecosystem services [2]. The term "underutilized" is generally used to refer to species whose potential has not been fully realized and exploited [3]. Those noncommodity crops, which are part of a larger biodiversity portfolio, once more popular and today neglected by user groups for a variety of agronomic, genetic, economic, social, and cultural factors [3]. Wild edible species can therefore contribute significantly to improved nutrition, income generation, and ecological sustainability $[4,5]$. There is an increasing focus on exploring opportunities to tap the potential of valuable underutilized wild plant species for food and nutritional security in the global context $[4,6]$.

Wild edible fruit species refer to fruit species that are neither cultivated nor domesticated but are accessible from various natural ecosystems and exploited for food [7]. It usually refers to noncultivated plants gathered from natural ecosystems [8]. The species grow spontaneously in selfmaintaining populations in natural or seminatural ecosystems, without human intervention for conservation and management actions $[9,10]$.

Wild edible plant species (WEPs) are valuable resources for improving the food and nutritional security of households [11-13]. These species play a great role in supplementary food provision, closing food gaps during periods of famine and droughts $[6,14]$, diversification of agricultural production, and generation of income for 
smallholder farming households [2, 6, 15-18]. Cultivation and utilization of wild plants is an unexploited opportunity to alleviate malnutrition and ameliorate food insecurity in the country.

Many communities traditionally use wild edible (fruit) species for food, oil, or medicine, but their potential uses have not further developed [4]. Over 413 wild edible plant species are gathered and consumed by local people in Ethiopia [13]. The largest number of edible wild plant species in the country is found to be trees with fruits $[11,15,16,19]$. Thus, the focus of the review inclined towards wild edible fruit species.

Ethiopia has been affected by recurring drought and famine, but the coping mechanisms were largely sourced from foreign aid rather than being inward-looking and development-oriented [20]. Despite the wide availability and utilization of wild edible fruit species in Ethiopia, ethnobotanical documentation, nutritional analysis, domestication, and conservation interventions are limited [12, 13]. Many fruit species are collected from wild resources and got little cultivation and conservation interventions. They get little attention or are entirely ignored by agricultural researchers, plant breeders, and policymakers $[8,13]$. The reasons include lack of information on the socio-economic contribution of the species for rural communities, lack of global markets, and production incentive-based fruit production [1].

Domestication and cultivation of species is a very convenient option to relieve the pressure on valuable and threatened wild populations and species, contributing both to conservation and overall socioeconomic developmental objectives. The domestication of locally marketed indigenous fruit trees contributes to the diversification of production and rural incomes and enhancement of the livelihoods of rural communities [1,21]. The increased planting and management of the indigenous and wild edible fruit trees also help to restore degraded ecosystems and conserve their declining diversity [1]. This involves the selection or prioritization, improvement of productivity, and developing marketing strategies of the most highly valued wild/indigenous fruit trees. Setting priorities, however, requires an understanding of user needs and preferences. It is now widely accepted that domestication is likely to be most effective when local people are involved in a participatory process of priority-setting for tree species [22].

The potential of wild edible species has not been fully realized and exploited. Agricultural scientific efforts have largely focused on major crops and staples, thereby neglecting local crop diversity and associated traditional knowledge and cultures [23]. This work aimed to review the domestication potential of wild-edible fruit species, assess past progress on wild-edible fruit species domestication activities, and designate strategies for enhanced domestication and cultivation of underutilized but crucial wild edible fruits in Ethiopia. In this review, wild edible fruit species are used to refer mainly to indigenous and underutilized wild edible fruit woody species.

\section{Wild-Edible Fruit Species Utilization in Ethiopia}

Wild edible plants are valuable resources forming local survival strategies in food-insecure areas in Ethiopia [24] and for improving the food and nutritional security of households $[11,12]$. Rural communities have a strong social and economic attachment to indigenous fruit trees [25]. It is shown that wild edible foods are integral parts of the feeding habits of many communities in most parts of Ethiopia [26]. The consumption of wild edibles is more common in food-insecure areas than in other areas in the country $[13,27]$. Young children are passionate about wild fruits from which they are likely to derive valuable nutrients [15]. However, food-secure households also regularly enjoy wild edible fruits and plants at some time of the year. It could be surprising that the only sources of nutrition in remote rural communities are wild edible fruits where the domestic fruits are absent in their farming systems and the local markets $[6,17]$.

The collection and utilization of wild edible fruits are integral parts of livelihood strategies (Table 1) and food systems for different communities in Ethiopia [24]. The community consumes wild edible plants for supplementing staple food, filling seasonal food shortages, and emergency food during a famine in Ethiopia [15, 16, 30, 33, 35]. Those species are primarily utilized for household consumption and are a potential food source in the future $[11,15]$. However, much of the research studies on wild edible fruit and plants misunderstood their role in many communities. Many researchers wrongly concluded that the utilization of wild edible fruits is food insecure for poor people and children. The reality is that food secure households and adults regularly enjoy wild edible fruits and plants [6].

Many marketable wild edible fruits (Table 2) have also made considerable contributions to income generation $[17,30,35,37,38]$. Several wild edible fruits are on the local markets and are an important source of income $[1,30]$. However, the available information on the contribution of indigenous edible fruit species for both household consumption and annual income is very scarce in Ethiopia [18]. Past studies have not gone beyond simply listing the species, and this indicates research gaps on practical aspects for the development of the species.

The other important aspect of many wild edible tree species is their multipurpose utilization $[15,24,39]$. Besides fruit production, the species are important for medical purposes, fodder, fuel-wood, and timber production (Table 3). Many wild edible fruit species are widely used and valued for traditional medicine in many countries $[6,37]$. This multipurpose nature of the species could be a plausible rationale to further motivate the domestication and wider cultivation of the species.

\section{Why Domesticating Wild Fruit Species?}

Domestication entails the naturalization of and settling of a species in human-induced agroecosystems. It is an accelerated evolutionary process of human-induced change 
TABLE 1: Widely utilized wild edible fruit species in different geographic locations of Ethiopia.

\begin{tabular}{|c|c|c|c|c|}
\hline No. & Species name & Family name & Geographic location & Source \\
\hline 1. & $\begin{array}{c}\text { Balanites } \\
\text { aegyptiaca }\end{array}$ & Balanitaceae & $\begin{array}{l}\text { Northeastern Ethiopia, northern Ethiopia, northwestern Ethiopia, } \\
\text { central Ethiopia, southern Ethiopia, eastern Ethiopia }\end{array}$ & {$[11,12,18,24,28,29]$} \\
\hline 2. & $\begin{array}{l}\text { Balanites } \\
\text { rotundifolia }\end{array}$ & Balanitaceae & Semiarid lowland, southern Ethiopia, southern Ethiopia & {$[30,31]$} \\
\hline 3. & $\begin{array}{l}\text { Berchemia } \\
\text { discolor }\end{array}$ & Rhamnaceae & Eastern Ethiopia & {$[32]$} \\
\hline 4. & Carissa spinarum & Apocynaceae & $\begin{array}{c}\text { Southern Ethiopia, central Ethiopia, western Ethiopia, northwestern } \\
\text { Ethiopia, northwestern Ethiopia }\end{array}$ & {$[12,16,18,33]$} \\
\hline 5. & Cordia africana & Boraginaceae & $\begin{array}{c}\text { Southern Ethiopia, central Ethiopia, northwestern Ethiopia, northern } \\
\text { Ethiopia, northeastern Ethiopia }\end{array}$ & {$[11,12,24,29,33,34]$} \\
\hline 6. & Cordia monoica & Boraginaceae & Eastern Ethiopia & {$[32]$} \\
\hline 7. & $\begin{array}{l}\text { Diospyros } \\
\text { mespiliformis }\end{array}$ & Ebenaceae & Northwestern Ethiopia & {$[33]$} \\
\hline 8. & Dobera glabra & Salvadoraceae & Southern Ethiopia, eastern Ethiopia & {$[31,32]$} \\
\hline 9. & $\begin{array}{l}\text { Dovyalis } \\
\text { abyssinica }\end{array}$ & Flacourtiaceae & Northwestern Ethiopia, northeastern Ethiopia & {$[33,34]$} \\
\hline 10. & Ficus sur & Moraceae & $\begin{array}{c}\text { Northwestern Ethiopia, western Ethiopia, central Ethiopia, southern } \\
\text { Ethiopia }\end{array}$ & {$[11,12,16,24]$} \\
\hline 11. & Ficus vasta & Moraceae & Semiarid lowland, southern Ethiopia & {$[30]$} \\
\hline 12. & Flacourtia indica & Flacourtiaceae & Semiarid lowland, southern Ethiopia, southern Ethiopia & {$[24,30]$} \\
\hline 13. & $\begin{array}{l}\text { Garcinia } \\
\text { livingstonei }\end{array}$ & Clusiaceae & Central Ethiopia, southern Ethiopia & {$[18,31]$} \\
\hline 14. & $\begin{array}{l}\text { Gardenia } \\
\text { ternifolia }\end{array}$ & Rubiaceae & Western Ethiopia, northwestern, Ethiopia & {$[12,16]$} \\
\hline 15. & Grewia villosa & Tiliaceae & Eastern Ethiopia & [32] \\
\hline 16. & Manilkara butugi & Sapotaceae & Eastern Ethiopia, southern Ethiopia & {$[31,32]$} \\
\hline 17. & Meyna tetraphylla & Rubiaceae & Semiarid lowland, southern Ethiopia & {$[30]$} \\
\hline 18. & $\begin{array}{l}\text { Mimusops } \\
\text { kummel }\end{array}$ & Sapotaceae & Northwestern Ethiopia, northern Ethiopia, northeastern Ethiopia & {$[29,33,34]$} \\
\hline 19. & $\begin{array}{l}\text { Opuntia ficus- } \\
\quad \text { indica }\end{array}$ & Cactaceae & $\begin{array}{c}\text { Northern Ethiopia, central Ethiopia, southern Ethiopia, semiarid } \\
\text { lowland, southern Ethiopia }\end{array}$ & {$[11,18,24,29,30]$} \\
\hline 20. & Phoenix reclinata & Arecaceae & Western Ethiopia & [16] \\
\hline 21. & Rosa abyssinica & Rosaceae & Central Ethiopia & {$[11,18]$} \\
\hline 22. & Salvadora persica & Salvadoraceae & Semiarid lowland, southern Ethiopia, eastern Ethiopia & {$[30,32]$} \\
\hline 23. & Sclerocarya birrea & Anacardiaceae & Semiarid lowland, southern Ethiopia & [30] \\
\hline 24. & Strychnos spinosa & Loganiaceae & Northwestern, Ethiopia & {$[12]$} \\
\hline 25. & $\begin{array}{l}\text { Syzygium } \\
\text { guineense }\end{array}$ & Myrtaceae & $\begin{array}{c}\text { Northwestern Ethiopia, northeastern Ethiopia, western Ethiopia, } \\
\text { southern Ethiopia }\end{array}$ & {$[12,16,24,30,33]$} \\
\hline 26. & $\begin{array}{l}\text { Tamarindus } \\
\text { indica }\end{array}$ & Fabaceae & $\begin{array}{c}\text { Northwestern Ethiopia, semiarid lowland, southern Ethiopia, eastern } \\
\text { Ethiopia }\end{array}$ & {$[12,30,32,33]$} \\
\hline 27. & Vitex doniana & Lamiaceae & Western Ethiopia, southern Ethiopia & {$[16,31]$} \\
\hline 28. & $\begin{array}{c}\text { Ximenia } \\
\text { americana }\end{array}$ & Olacaceae & $\begin{array}{l}\text { Northwestern Ethiopia, northern Ethiopia, central Ethiopia, eastern } \\
\text { Ethiopia, southern Ethiopia, semiarid lowland, southern Ethiopia }\end{array}$ & {$[12,18,24,29-33]$} \\
\hline 29. & $\begin{array}{l}\text { Ziziphus } \\
\text { mucronata }\end{array}$ & Rhamnaceae & Eastern Ethiopia & {$[32]$} \\
\hline 30. & $\begin{array}{l}\text { Ziziphus spina- } \\
\text { christi }\end{array}$ & Rhamnaceae & Northeastern Ethiopia, northern Ethiopia, central Ethiopia & {$[11,29,34]$} \\
\hline
\end{tabular}

in the biological characteristics of a species to conform to human needs and agroecosystems [40, 41]. Domestication and improving the productivity of wild edible species and underutilized species is a vital way and prerequisite for increased and sustainable production and conservation $[11,17,42]$. Increased cultivation of wild edible fruits will diversify farming systems, improve the connectivity of remaining natural habitats for biodiversity conservation, and conserve decrease genetic resources of the species by reducing the pressure on natural stands of the species [43].

Domestication of wild edible fruits has many production-related economic and social roles [41]. The domestication of promising indigenous wild edible fruits will ultimately have a positive impact on the livelihoods of rural societies [15]. Domestication leads to sustainable and increased production which could contribute to improved nutritional security [4] and diversified income opportunities for small-scale farmers [23, 41, 44]. However, the scientific intervention to domesticate the species is behind the farmer's practice [18]. Many indigenous fruits are still extracted from natural ecosystems which have normally limited potential for higher growth and yields [40]. Furthermore, the collection of wild edible fruits from natural ecosystems requires significant time and labor. Therefore, 
TABLE 2: Marketable wild edible fruit species in different geographic locations of Ethiopia.

\begin{tabular}{|c|c|c|c|c|}
\hline No. & Species name & Family name & Geographic location & Source \\
\hline 1. & Adansonia digitata & Malvaceae & Northern Ethiopia & {$[34,36]$} \\
\hline 2. & Annona senegalensis & Annonaceae & Southeastern Ethiopia, southwestern Ethiopia & {$[36]$} \\
\hline 3. & Balanites aegyptiaca & Balanitaceae & Northern Ethiopia & {$[34,36]$} \\
\hline 4. & Balanites rotundifolia & Balanitaceae & Southern Ethiopia & {$[30,31]$} \\
\hline 5. & Berchemia discolor & Rhamnaceae & Northwestern Ethiopia, eastern Ethiopia & {$[19,32]$} \\
\hline 6. & Carissa spinarum & Apocynaceae & Northwestern Ethiopia, northern Ethiopia & {$[19,34,36]$} \\
\hline 7. & Cordia africana & Boraginaceae & Northern Ethiopia & {$[34,36]$} \\
\hline 8. & Diospyros mespiliformis & Ebenaceae & Northwestern Ethiopia, northern Ethiopia & {$[19,34,36]$} \\
\hline 9. & Dobera glabra & Salvadoraceae & Eastern Ethiopia & [32] \\
\hline 10. & Dovyalis abyssinca & Flacourtiaceae & Northern Ethiopia, southwestern Ethiopia & {$[34,36]$} \\
\hline 11. & Ficussur & Moraceae & Northwestern Ethiopia & [19] \\
\hline 12. & Ficus sycomorus & Moraceae & Eastern Ethiopia & {$[32]$} \\
\hline 13. & Flacourtia indica & Flacourtiaceae & Southeastern Ethiopia & {$[36]$} \\
\hline 14. & Grewia villosa & Tiliaceae & Eastern Ethiopia & [32] \\
\hline 15. & Manilkara butugi & Sapotaceae & Southern Ethiopia, eastern Ethiopia & {$[31,32]$} \\
\hline 16. & Meyna tetraphylla & Rubiaceae & Southern Ethiopia & {$[30]$} \\
\hline 17. & Mimusops kummel & Sapotaceae & Northwestern Ethiopia, northern Ethiopia, southeastern Ethiopia & {$[19,34,36]$} \\
\hline 18. & Opuntia ficus-indica & Cactaceae & Northern Ethiopia, southern Ethiopia & {$[30,34,36]$} \\
\hline 19. & Rosa abyssinica & Rosaceae & Northern Ethiopia & {$[34,36]$} \\
\hline 20. & Sclerocarya birrea & Anacardiaceae & Southern Ethiopia & {$[30]$} \\
\hline 21. & Syzygium guineense & Myrtaceae & $\begin{array}{c}\text { Northwestern Ethiopia, northern Ethiopia, southern Ethiopia, } \\
\text { southeastern Ethiopia, southwestern Ethiopia }\end{array}$ & {$[19,31,34,36]$} \\
\hline 22. & Tamarindus indica & Fabaceae & $\begin{array}{c}\text { Northwestern Ethiopia, northern Ethiopia, eastern Ethiopia, southeastern } \\
\text { Ethiopia }\end{array}$ & {$[19,32,34,36]$} \\
\hline 23. & $\begin{array}{l}\text { Vangueria } \\
\text { madagascariensis }\end{array}$ & Rubiaceae & Southern Ethiopia & {$[31]$} \\
\hline 24. & Vitex doniana & Lamiaceae & Southern Ethiopia & {$[31]$} \\
\hline 25. & Ximenia americana & Olacaceae & $\begin{array}{c}\text { Northwestern Ethiopia, northern Ethiopia, eastern Ethiopia, southeastern } \\
\text { Ethiopia, southwestern Ethiopia }\end{array}$ & {$[19,32,34,36]$} \\
\hline 26. & Ziziphus spina-christi & Rhamnaceae & Northwestern Ethiopia, northern Ethiopia, eastern Ethiopia & {$[19,32,34,36]$} \\
\hline
\end{tabular}

domestication and on-farm cultivation of the species are supposed to be cost-effective.

Domestication of wild edible fruit species has more than production benefits (Table 3 ); it has also social and ecological benefits [44]. It is an essential strategy to enhance biodiversity and reduce the pressure on natural ecosystems $[11,15,24,45]$. Several species would be further endangered and threatened with extinction if they would be left on their own without measures for conservation, cultivation, and promotion $[15,46]$. The occurrence of wild edible fruit species is restricted to few scattered trees in natural ecosystems. The wild edible fruit species such as Ziziphus spinachristi, Balanites aegyptiaca, Cordia africana, Rosa abyssinica, Carissa spinarum, Ziziphus mucronata, Ximenia americana [11, 34], Syzygium guineense [24, 34], Tamarindus indica, Balanites aegyptiaca, Ziziphus spina-christi, Salvadora persica, Berchemia discolor, and Ximenia americana [32] are also locally threatened species in many parts of Ethiopia. The reasons are harvesting pressure for food and other uses [32] and ecosystem degradation associated with deforestation, overgrazing, and other treats.

Researchers are indicating the importance of formal research investment [40], domestication, and on-farm management of useful priority wild edible species to attain nutritional and economic benefit in Ethiopia [13, 15, 19, 37]. This correspondingly indicates the instant need for identification, prioritization, and promotion of wild edible fruit species to promote nutritional security and conserve the biological diversity of the species.

\section{Priority Wild Edible Fruit Species for Domestication in Ethiopia}

East African regions have many potentials and priority indigenous woody species for domestication, particularly in the semiarid lowlands $[17,42]$. Large numbers of tree species exist in all ecoregions, which potentially could be domesticated to produce marketable products [21]. An estimated $8 \%$ of the total 7000 higher plants in Ethiopia are edible, including woody fruit-bearing species $[15,47]$.

Without identification of which wild edible species are prior, the potential of species cannot be effectively developed and utilized. Prioritization is necessary to draw full attention to the more promising species. The first step in the overall domestication and profitable exploitation of a wild edible species is identifying the most promising species for domestication in a region [21]. The choice of which trees to domesticate should follow a priority setting that identifies the most highly valued species [22].

Priority setting requires an understanding of biological characteristics, socioeconomic needs and preferences, technological opportunities, and systematic methods for ranking species prioritization [48]. The prioritization of wild edible fruit species is based on weighting factors including 
TABle 3: Common wild edible fruit tree and shrub species.

\begin{tabular}{|c|c|c|c|c|c|c|}
\hline $\begin{array}{l}\mathrm{S} / \\
\mathrm{N}\end{array}$ & Scientific name & Family & Vernacular name & Local name & Growth habit & Other uses \\
\hline 1 & Adansonia digitata & Bombacaceae & Baobab & Bamba & Tree & $1,2,3,4,5,7,9$ \\
\hline 2 & Annonasenegalensis & Annonaceae & Wild custard apple & Yebere lib & Shrub tree & $1,2,4,5$ \\
\hline 3 & Balanites aegyptiaca & Balanitaceae & Desert date & Bedeno & Tree & $1,2,3,5,6,7$ \\
\hline 4 & Balanites rotundifolia & Balanitaceae & - & Kuzo/Murko & Shrub tree & $2,3,4,6,7$ \\
\hline 5 & Berchemia discolor & Rhamnaceae & Wild almond & Jejeba & Shrub or tree & $2,4,5,9$ \\
\hline 6 & Bridelia micrantha & Euphorbiaceae & Coast goldleaf & YenebirTifir & Shrub or tree & $2,3,4,5,7$ \\
\hline 7 & Carissa spinarum & Apocynaceae & Bush plum & Agam & Shrub & $3,5,6,7,8$ \\
\hline 8 & Cordia africana & Boraginaceae & Sudan teak & Wanza & Tree & $2,3,5,7$ \\
\hline 9 & Cordia monoica & Boraginaceae & Sandpaper saucer-berry & $\begin{array}{l}\text { Mintiro/Qeya- } \\
\text { wanza }\end{array}$ & Shrub or tree & $3,4,5,9$ \\
\hline 10 & Diospyros mespiliformis & Ebenaceae & $\begin{array}{c}\text { Jackal-berry/African } \\
\text { ebony }\end{array}$ & Betere muse & Tree & $2,3,4,5,6,9$ \\
\hline 11 & Dobera glabra & Salvadoraceae & - & Garsa & Shrub or tree & $1,2,3$ \\
\hline 12 & Dovyalis abyssinca & Flacourtiaceae & African gooseberry & Koshum & Shrub & $3,5,6,9$ \\
\hline 13 & Eriobotrya japonica & Rosaceae & Loquat/Japan-plum & Weshmela & Shrub or small tree & $2,3,4,5,6,7,9$ \\
\hline 14 & Ficus sur & Moraceae & Fig tree & Shola & Tree & $4,5,10$ \\
\hline 15 & Ficus sycomorus & Moraceae & Sycamore of the Bible & Bamba & Tree & $2,3,4,5,7,10$ \\
\hline 16 & Ficus vasta & Moraceae & Fig tree & Warka & Tree & $3,4,10$ \\
\hline 17 & Flacourtia indica & Flacourtiaceae & Indian plum & Akuku & Shrub or tree & $2,3,4,5,6$ \\
\hline 18 & Gardenia ternifolia & Rubiaceae & Large-leaved gardenia & - & Shrub or small tree & 9 \\
\hline 19 & Garcinia livingstonei & Clusiaceae & African mangosteen & - & Shrub or small tree & $2,3,4,5,7$ \\
\hline 20 & Grewia villosa & Tiliaceae & $\begin{array}{c}\text { Mallow-leaved ross } \\
\text { berry }\end{array}$ & Agobday & Shrub & $2,3,5$ \\
\hline 21 & Manilkara butugi & Sapotaceae & Chicle tree/naseberry & Butigi & Tree & $3,4,5$ \\
\hline 22 & Meyna tetraphylla & Rubiaceae & - & - & Shrub & 5,6 \\
\hline 23 & Mimusops kummel & Sapotaceae & Red milkwood & Eshi & Tree & $3,4,5$ \\
\hline 24 & Oncoba spinosa & Flacourtiaceae & Wild rose & Ekuku & Shrub or small tree & $3,4,5$ \\
\hline 25 & Opuntia ficus-indica & Cactaceae & Prickly pear & Qulqual & $\begin{array}{c}\text { Succulent shrub or } \\
\text { tree }\end{array}$ & $2,6,7$ \\
\hline 26 & Phoenix reclinata & Arecaceae & Wild date palm & Zenbaba & Tree & $2,3,4,5,7,10$ \\
\hline 27 & Rosa abyssinica & Rosaceae & Abyssinian rose & Kega & Shrub & $3,6,5$ \\
\hline 28 & Salvadora persica & Salvadoraceae & Toothbrush tree & Yeharer-mefaqya & Shrub or tree & $2,3,5,7,10$ \\
\hline 29 & Sclerocarya birrea & Anacardiaceae & Marula tree & Didissa/Didigssa & Tree & $1,2,4,6,5,10$ \\
\hline 30 & Strychnos spinosa & Loganiaceae & Spiny monkey orange & Merenz & Shrub or tree & $2,3,4,5$ \\
\hline 31 & Syzygium guineense & Myrtaceae & Waterberry & Dokma & Tree & $3,4,5,9,10$ \\
\hline 32 & Tamarindus indica & Fabaceae & Tamarind & Roqa/Homer & Tree & $2,3,4,5,7$ \\
\hline 33 & $\begin{array}{c}\text { Vangueria } \\
\text { madagascariensis }\end{array}$ & Rubiaceae & Spanish tamarind & - & Shrub & $3,5,9$ \\
\hline 34 & Vitex doniana & Lamiaceae & Black plum & Plem & Tree & $2,3,4,5,7,9,10$ \\
\hline 35 & Ximenia americana & Olacaceae & Wild plum & Inkoy & Large shrub or tree & $2,3,4,5,6$ \\
\hline 36 & Ziziphus mauritiana & Rhamnaceae & Jujube & Qurqurah & Large shrub or tree & $2,3,4,5,6,7$ \\
\hline 37 & Ziziphus spina-christi & Rhamnaceae & Christ's thorn jujube & Qurqurah & Large shrub or tree & $2,3,4,5,6,7,10$ \\
\hline
\end{tabular}

1: food (leaves, seeds, or other parts); 2: fodder; 3: fuel-wood; 4: timber or pole; 5: medicinal value; 6: fencing; 7: soil conservation/improvement; 8: land rehabilitation; 9: others, e.g., bee forage; 10: shade or ornamental.

current utilization extent, preference of community, marketability or socio-economic value, availability in natural ecosystems $[16,25,26,36,38]$, and technical experience of farming communities on management of the species [49]. The multipurpose nature and conservation status are also important considerations for the prioritization of species $[3,4]$. Thus, the domestication and promotion of wild edible fruit species are better based on understanding the characteristics and considerations.

The criteria (weighting factors) for prioritization will vary with local, national, and regional needs and policies for promoting specific species [21]. The species selection depends on the objectives of the domestication, varies for income generation, conservation, or farm diversification. It may also vary among localities, regions, and countries $[19,25,34,49]$. In general, the most commonly utilized, preferred, and marketable wild edible fruit species deserve priority action for domestication and conservation in natural forests $[42,48]$. Thus, employing priority setting criteria and procedures based on evident local variations and needs is appropriate and perhaps inevitable from the scientific and practical point of view.

Preference ranking and market survey are the main methods to guide the process of species prioritization $[48,49]$. Farmers have different preference of tree species to grow on their farms based on perceived ecological and 
economic usefulness of species $[50,51]$. Some species may also be a priority if the species has expanding market and high-income generation potential [52]. This shows that there should be a clear economic, social, and/or ecological justification for a wild fruit species to be priority.

Moreover, the conservation status of wild fruit species also indicates the priority of a wild species. Several wild fruit species (e.g., Syzygium guineense [24, 34], Tamarindus indica, and Ximenia americana [32]) were represented only by few individuals in natural ecosystems [32]. This decline in wild ecosystems and the tendency of framers to preserve some fruit-bearing species on farmlands $[1,47,53]$ shows the perceived roles of the species. Thus, wider on-farm cultivation practices and utilization are desirable to conserve the species by 'conservation through use' approach [2, 40].

Some research attempts were made on preference ranking for wild edible species in different regions of Ethiopia [12, 29, 31, 32]. However, they are fragmented and their aim is the fulfillment of educational requirements rather than for the economic development of the species. Thus, the need for more strategic and comprehensive research on wild edible species at the national level is obvious to address local needs and opportunities of all possible distinct ecological regions and socio-economic circumstances. Most preferred wild edible fruit species in Ethiopia according to different sources are illustrated in Table 4.

The review summarized information on priority wild fruit species for domestication and improvement in Ethiopia based on their wider utilization and multiple use, preference rankings, and marketability of the fruits and conservation status (Table 5). The assumption on the weighing factors is that wider utilization, marketability, and high preference for a species implicate with the technical experiences of farmers on the management and production of the species.

Based on these weighted factors, suggested priority species include Ziziphus spina-christi, Balanites aegyptiaca, Ximenia americana, Dobera glabra, Carissa spinarum, Tamarindus indica, Syzygium guineense, Mimusops kummel, Berchemia discolor, Dovyalis abyssinica, Vitex doniana, and Berchemia discolor (Table 4). However, it should be noted that area-specific prioritization of the fruit species may result in a different set of priority species. Moreover, some wild edible fruit species which have been well-researched and relatively developed in Ethiopia or other African countries are also not included in the priority list. The relatively wellresearched species include Opuntia ficus-indica, Sclerocarya birrea, Adansonia digitata, Vitellaria paradoxa, and Strychnos spinosa among others.

The suggested priority wild edible fruit species, e.g., Tamarindus indica and Ziziphus spina-christi, have a high potential for domestication and cultivation due to their nutritional and regional commercial value in other countries. Fruit species such as Balanites aegyptica, Carissa edulis, Mimusops kummel, Sclerocarya birrea, and Vitellaria paradoxa are previously identified as priority indigenous fruit trees in Ethiopia [37, 38].

Some of the priority indigenous fruit tree species are also previously identified for domestication and wider utilization in the drylands of eastern Africa. The identified priority species include Adansonia digitata, Carissa spinarum, Sclerocarya birrea, Strychnos spinosa, Tamarindus indica, Ziziphus mauritiana, Vitex doniana, Balanites aegyptiaca, Berchemia discolor, Ximenia americana, and Vangueria madagascariensis [1, 36, 49]. The species are underutilized due to limited domestication and commercialization intervention only in Ethiopia [13].

\section{Domestication Efforts on Wild-Fruit Species in Ethiopia}

African native fruit species have not been developed to their full potential in terms of product quality, the scale of production and distribution, product processing, and value addition [40]. Only a few indigenous species have been chosen for domestication, among the large number of important wild species grown by smallholder farmers in the eastern African region. Knowledge and technical know-how of propagation and associated skills for indigenous fruit trees are more or less lacking in Ethiopia [36]. Scientifically planned selection and breeding programs have not been largely undertaken for indigenous fruit species in eastern Africa [40], though the need for such a plan is generally recognized.

The entire evolutionary development of domestication and utilization of fruit trees is left for the farmers in Africa [64]. This pathway of domestication is generally not common in history for wild fruit species and not working effectively in current times due to competing market and production potential of exotic fruit species and lack of scientific support for improvement on the productivity of wild fruits. This is why valuable indigenous tree species are often found only to a low extent and on few plots of agricultural and agroforestry farms [43]. In general, progress in the domestication and improvement of indigenous fruit tree species has been slow [45].

Discussions on some domestication thoughts are imperative towards thoroughly address past domestication efforts. Two main ways within a domestication strategy could be identified [65]. The first one is the traditional onfarm domestication and cultivation by farmers themselves. The second is a scientific approach to domestication through genetic improvement on research stations and on-farm participatory researches [21]. The first way is generally not common in the history of wild fruit species and not working effectively in current times. This is because plant domestication in the history of the country is biased towards shortlived plants (annual or biennial crops) [13].

Despite the wide availability and utilization of wild edible plants in Ethiopia, there is still limited ethnobotanical documentation, nutritional analyses, socioeconomic assessments, and domestication experience. Fruit-bearing wild edible plants suffer notable disregard from formal research and development initiatives in the country [24, 38]. A review on seedling production showed seedling is not produced for all the abovementioned widely utilized and marketed wild edible fruit species in large numbers of tree nurseries in the country [66]. The review detected very limited scientific interventions and experiences on selection of genetically 
TABLE 4: Most preferred wild edible fruit species in Ethiopia.

\begin{tabular}{|c|c|c|c|}
\hline No. & Location & Scientific name & Source \\
\hline 1. & Western Ethiopia & Syzygium guineense & {$[16]$} \\
\hline 2. & $\begin{array}{l}\text { Northwestern } \\
\text { Ethiopia }\end{array}$ & Gardenia ternifolia & {$[53]$} \\
\hline 3. & Central Ethiopia & Ziziphus spina-christi, Balanites aegyptiaca, Ximenia americana & {$[54]$} \\
\hline 4. & Southern Ethiopia & Carissa spinarum, Ficussur, Cordia africana, Syzygium guineense & {$[24]$} \\
\hline 5. & Southern Ethiopia & Balanites rotundifolia, Vitex doniana, Manilkara butugi, Carissa spinarum, Garcinia livingstonei & {$[31]$} \\
\hline 6. & $\begin{array}{l}\text { Northeastern } \\
\text { Ethiopia }\end{array}$ & Ziziphus spina-christi, Cordia africana, Balanites aegyptiaca, & {$[34]$} \\
\hline 7. & $\begin{array}{l}\text { Northwestern } \\
\text { Ethiopia }\end{array}$ & Ziziphus spina-christi, Tamarindus indica, Syzygium guineense, Carissa spinarum, Ximenia americana & [47] \\
\hline 8. & Northern Ethiopia & $\begin{array}{c}\text { Opuntia ficus-indica, Ziziphus spina-christi, Mimusops kummel, Balanites aegyptiaca, Ximenia } \\
\text { americana, Cordia africana }\end{array}$ & {$[29]$} \\
\hline 9. & Eastern Ethiopia & Balanites aegyptiaca, Grewia villosa, Salvadora persica, Ziziphus mucronata, Tamarindus indica & {$[32]$} \\
\hline 10. & $\begin{array}{l}\text { Northwestern } \\
\text { Ethiopia }\end{array}$ & $\begin{array}{c}\text { Syzygium guineense, Dovyalis abyssinica, Carissa spinarum, Mimusops kummel, Diospyros } \\
\text { mespiliformis, Ximenia americana and Cordia africana }\end{array}$ & [19] \\
\hline 11. & Central Ethiopia & Ziziphus spina-christi, Balanites aegyptiaca, Cordia africana, Rosa abyssinica, Carissa spinarum & {$[11]$} \\
\hline 12. & $\begin{array}{l}\text { Northwestern } \\
\text { Ethiopia }\end{array}$ & $\begin{array}{c}\text { Vitex doniana, Tamarindus indica, Balanites aegyptiaca, Syzygium guineense, Ziziphus spina-christi, } \\
\text { Oncoba spinosa }\end{array}$ & [12] \\
\hline
\end{tabular}

TABLE 5: Suggested priority wild edible fruit species for domestication and improvement in Ethiopia.

\begin{tabular}{|c|c|c|c|}
\hline No. & Priority species & Justification & Source \\
\hline 1. & $\begin{array}{l}\text { Ziziphus spina- } \\
\text { christi }\end{array}$ & $\begin{array}{l}\text { A multipurpose tree with high nutrient content and high commercial value. The species is also highly } \\
\text { valued for fodder, timber, fuelwood, fencing, and medicinal values. It is a promising drought-tolerant } \\
\text { agroforestry species for arid regions. }\end{array}$ & {$[55]$} \\
\hline 2. & $\begin{array}{l}\text { Balanites } \\
\text { aegyptiaca }\end{array}$ & $\begin{array}{l}\text { A multipurpose tree with fruit, leaves, and extracted oil from seeds used for food and high agro- } \\
\text { industrial exploitation. It is also very important for fodder, fencing, fuel-wood, and charcoal } \\
\text { production. The species is under high harvesting and browsing pressure, indicating the need for } \\
\text { conservation. }\end{array}$ & {$[37,56]$} \\
\hline 3. & $\begin{array}{c}\text { Ximenia } \\
\text { americana }\end{array}$ & $\begin{array}{l}\text { A most preferred multipurpose tree for fruit, medicine, fodder, and other uses. The species have the } \\
\text { potential to diversity food and improve nutrition and have considerable market value for income } \\
\text { generation. The species is rare and threatened, indicating the need for conservation and domestication. }\end{array}$ & {$[54]$} \\
\hline 4. & Carissa spinarum & $\begin{array}{l}\text { A multipurpose shrub with highly nutritious and protein-rich fruits. It is also drought-resistant, } \\
\text { effective for fencing, and recommended species for land rehabilitation and soil conservation. }\end{array}$ & {$[57]$} \\
\hline 5. & Tamarindus indica & $\begin{array}{l}\text { A multipurpose tree that has the potential for food provision, fodder, timber, nutritional and medicinal } \\
\text { values. It has well-known and processed commercial products elsewhere (e.g., in India). It is a } \\
\text { recommended species for integration with cereal crops in farming systems. Furthermore, the species } \\
\text { under serious anthropogenic threats justify the need for its conservation. }\end{array}$ & {$[58]$} \\
\hline 6. & Vitex doniana & $\begin{array}{l}\text { Multipurpose species used for food and medicinal value; improve nutrition, locally and regionally } \\
\text { marketed for its fruit and leaves. The fruit has high sugar content and is used as a sweetener. It is locally } \\
\text { threatened with extinction mainly due to high utilization pressure, showing the need for conservation. }\end{array}$ & [59] \\
\hline 7. & Berchemia discolor & $\begin{array}{l}\text { A multipurpose tree mainly used for food (fruit), has high nutrient content and potential to improve } \\
\text { nutrition and good candidate agroforestry species. }\end{array}$ & {$[54]$} \\
\hline 8. & Dobera glabra & $\begin{array}{l}\text { An important wild food source (particularly in the Afar region, Ethiopia), potential fodder species, and } \\
\text { provide timber used for making household furniture }\end{array}$ & {$[60]$} \\
\hline 9. & Mimusops kummel & $\begin{array}{l}\text { A multipurpose species with testy marketable fruit, and provides other multiple uses including } \\
\text { medicinal value, timber, firewood, and charcoal }\end{array}$ & {$[61]$} \\
\hline 10. & $\begin{array}{l}\text { Syzygium } \\
\text { guineense }\end{array}$ & $\begin{array}{l}\text { A multipurpose wild edible fruit species. It is valuable for honeybee forage, medicinal value, and timber } \\
\text { and fuel-wood production. }\end{array}$ & {$[62]$} \\
\hline 11. & $\begin{array}{l}\text { Dovyalis } \\
\text { abyssinica }\end{array}$ & $\begin{array}{l}\text { The species has testy fruit and is an important ornamental hedge and live fencing species. The fruit has } \\
\text { the desired characteristic for processing jams, jellies, and juices. It has also medicinal value and used for } \\
\text { bee forage. }\end{array}$ & {$[63]$} \\
\hline
\end{tabular}

superior trees, genetic improvement, and production of planting stock of indigenous woody species and wild fruit species.

Research efforts to increase the production of indigenous fruit trees and make the improved genetic materials communicated on online resources are rare in Africa, including
Ethiopia [45]. Only farmers themselves traditionally preserve some fruit-bearing indigenous species on their farmlands $[1,47,53]$. Many wild fruit species are in the early stage of domestication (only by farmers using traditional selection). The farmers retain and manage naturally regenerated trees of the species (e.g., Banalities aegyptiaca and Ziziphus spina- 
christi) $[19,30]$. The farmers do not raise the trees from seedling and cultivate the species usually without selection of the superior varieties. The only remarkable effort towards domestication and improvement of wild edible species is the collection and selection of cultivars of cactus pear (Opuntia ficus-indica) carried out in Tigray, northern Ethiopia [28,67]. This species is moving towards domestication for its potential in dry areas in northern Ethiopia $[15,68]$.

The remark here is that wild fruit species discussed in this paper have the potential to justify the need for developing them into crops $[15,68]$. The official responsibility of domestication and improvement of indigenous wild fruit species is blurry for which sector it is assigned in Ethiopia. The horticultural sector gives a high concentration on exotic fruit species, while the forestry sector focuses on timber species. This is why some species (e.g., Opuntia ficus-indica and Tamarindus indica) are considered crops in other parts of the world, but not cultivated and collected from wild ecosystems in the country.

Many of the wild fruit species reported to have nutritional and commercial values in other countries (such as Adansonia digitata, Tamarindus indica, and Ziziphus mauritiana) are found to be underutilized in Ethiopia. Hence, policy and decision-makers must consider all available ethnobotanical information to develop regional and national plans for the conservation, management, and sustainable utilization of wild edible species of the country [13]. In general, scientific approaches and efforts for the domestication and cultivation of wild edible species are lacking in Ethiopia. Thus, remarkable changes in domestication and utilization of wild fruit species and high future efforts in Ethiopia are expected from the scientific and participatory approaches. Propagation and domestication of wild food plants should be started through the efforts of governmental and nongovernmental organizations [30].

The major traits to be improved for many wild fruit species are fruiting age, fruit size, taste, and pulp content [42]. Nutritional and sugar content of some wild fruit species are generally higher than the contents of cultivated fruits associated with their lower water content $[6,17]$. The first procedure for improving wild fruits is to characterize variations in fruit traits, and the selection of superior trees with large fruit size, good taste, and high pulp content. After this, it is better to reproduce vegetatively, rather than a seedbased selection process [40,69]. Moreover, shreds of evidence proved the improvement of many traits of wild fruits with the intensive cultivation and management on farmlands than under wild natural conditions [70]. The poor performance of wild fruits is mainly caused by limiting environmental constraints in wild habitats for the species. Thus, cultivation and management of selected superior wild fruit populations will bring substantial improvement in yield quantity, size, and pulp content of wild fruits.

\section{Domestication and Cultivation Strategies}

Research and development attentive on wild edible fruits could assist in narrowing the gap between population growth and food deficiency currently mounting in developing countries. Domestication of wild edible fruits involves species potential assessment, prioritization, improved germplasm development and propagation and production techniques, and product commercialization $[65,71]$. It requires priority setting, identifying superior phenotypes, and propagation of planting materials. This selection of potential wild species requires an adequate knowledge based on botanic characteristics, yield potential, preference, and needs of producers and consumers [21,37]. The wider cultivation of indigenous fruit trees needs research on existing production and utilization patterns, cultivars development, nutritional content analysis, developing postharvest storage methods, and product processing [72].

However, appropriate propagation, production, and processing techniques for most of the indigenous fruit species are nearly lacking compared to similar fruit species of tropical America and Asia [37, 40]. The wider cultivation and utilization of underutilized species is hampered by the limited availability of improved planting materials, lack of developed production technologies leading to low yields, insufficient information on economic contribution, undeveloped marketing strategies, and little interest of researchers and national policies $[4,49]$.

Thus, a planned domestication involves identification, management, and production of a desirable germplasm of a species [40]. The scientifically planned domestication for the wild edible fruits should specifically address the identification of promising species, selection of superior varieties, genetic improvement $[5,49]$, seedling production, and developing growing and postharvest technology, etc. [65]. Farmers must be able to have access to seedlings of the priority species for multiplication and distribution [40]. This again needs better communication on socioeconomic contribution of the species and mainstreaming the strategies in national policies $[4,5]$.

The long period it takes before enjoying tangible benefits from tree-based farming systems is one of the reasons that some farmers see it as a deterrent to the planned cultivation of indigenous fruit species $[5,40,46]$. Yield, yield quality, and other aspects of the species can be improved through genetic selection and improvement. This indicates the need to initiate focused tree improvement programs that would address the essential pomological needs of indigenous fruit trees of the African continent [40]. Thus, developing improved varieties for improved productivity and product quality is a central strategic intervention to make underutilized indigenous fruit species more commercially competitive $[23,49,64]$. It helps to overcome the longstanding lack of genetically superior planting materials constraining the wider cultivation of indigenous fruit species [64].

Participatory germplasm collection and improvement also play a vital role [64]. Domestication strategies are thought to consider the needs of the farmers and to be market-driven [22]. Thus, participatory breeding addresses the needs of farmers dictated by the needs of local adaptation and consumer preferences for individual crops [41]. This is because farmers know how to select particular trees for their large fruit size, yield potential, periodicity of production, and 
other characteristics [72]. For example, superior varieties of preferred fruit species (e.g., Adansonia digitata, Tamarindus indica, Vitellaria paradoxa, and Ziziphus mauritiana) were selected for genetic improvement by farmers and researches in the western Sahelian countries [45]. A research report from southern Cameron showed that farmer-driven domestication through selective planting of Dacryodes edulis fruit tree has resulted $66 \%$ fruit size increase on farms than those in the forest [71]. More examples are reported on the relevance and success experiences of participatory domestication in southern Africa [42] and the dry zone of West Africa [49].

The low production potential is also a major limitation of indigenous wild edible fruit species compared to exotic fruit trees [24, 43]. Farmers reacted to the strong demand and high selling prices of exotic fruits by planting many trees, for which planting material is easily available. It is, therefore, advisable to initiate selection and breeding programs for such species to increase production [30] since domestication leads to an increase in the size of harvested organs $[41,73]$.

Wider cultivation of wild edible plants could also be achieved through on-farm integration and fruit-based agroforestry systems [24, 47]. Indigenous fruits are adapted to the local environment, less susceptible to disease and pests, and can grow easily in integrated farming systems with low external inputs [18, 47]. Thus, local communities should be encouraged to cultivate wild edible plants on their farmlands $[11,16]$. Other useful management options for wild edible fruit species include developing sustainable harvesting techniques for natural ecosystems [15].

\section{Conclusion}

Wild edible fruit species have an appreciable role in supplementary food provision, income generation and diversification, nutritional security in different parts of Ethiopia. Moreover, the species are multipurpose, thereby important for fodder, fuel-wood, and timber production among others. However, the species are underutilized and threatened by growing harvesting pressures in natural ecosystems. Many edible fruit-bearing wild species are in the early stage of domestication by farmers with low production. Most indigenous fruit species have not been brought up to their full potential in terms of quality, the scale of production, and the market. This indicates a pressing need for domestication and improvement of some wild edible fruits for increased production, diversifying income for small-scale farmers, sustainable utilization, and conservation of the species.

The number of promising wild edible fruit species for domestication and wider cultivation is considerable in Ethiopia. The review identified widely utilized and priority wild edible fruit species based on their wider utilization, preference ranking by the user community, product marketability, and conservation needs for the species. The widely utilized and marketed priority wild edible fruit species for domestication and improvement include Ziziphus spinachristi, Balanites aegyptiaca, Ximenia americana, Dobera glabra, Carissa spinarum, Tamarindus indica, Syzygium guineense, Mimusops kummel, Berchemia discolor, Dovyalis abyssinica, Vitex doniana, and Berchemia discolor. The species hold promise for local fruit production, multiple products, agroforestry development, and degraded land restoration and can grow under low management in smallholder systems.

Devising and implementing domestication and cultivation strategies will help to develop wild edible fruit species to their full potential in Ethiopia. The key future strategies for domestication and wider cultivation of wild edible fruit species include identifying and selecting priority and preferred species, strengthening botanical information, germplasm collection and genetic improvement, developing propagation, production, and processing technologies, increasing the supply of high-quality planting materials, and promoting on-farm cultivation in the form of agroforestry systems. Research should focus on genetic improvement, fruit processing, and species-specific analysis of economic contribution.

\section{Data Availability}

The data supporting this review are from previously reported studies and datasets, which have been cited.

\section{Conflicts of Interest}

The authors declare that they have no conflicts of interest.

\section{References}

[1] Z. Teklehaimanot, "The role of indigenous fruit trees in sustainable dryland agriculture in Eastern Africa," Indigenous Fruit Trees in the Tropics: Domestication, Utilization and Commercialization, CABI, Wallingford, UK, pp. 204-223, 2008.

[2] S. S. Ratnayake, L. Kumar, and C. S. Kariyawasam, "Neglected and underutilized fruit species in Sri Lanka: prioritisation and understanding the potential distribution under climate change," Agronomy, vol. 10, no. 1, p. 34, 2020.

[3] S. Padulosi and I. Hoeschle-Zeledon, "Underutilized plant species: what are they?" Leisa-Leusden, vol. 20, pp. 5-6, 2004.

[4] R. K. Arora, Diversity in Underutilized Plant Species: An AsiaPacific Perspective, p. 203, Bioversity International, New Delhi, India, 2014.

[5] H. Jaenicke, Strategic Framework for Underutilized Plant Species Research and Development: With Special Reference to Asia and the Pacific, and to Sub-Saharan Africa, Bioversity International, New Delhi, India, 2006.

[6] H. T. Duguma, "Wild edible plant nutritional contribution and consumer perception in Ethiopia," International Journal of Food Science, vol. 2020, Article ID 2958623, 16 pages, 2020.

[7] S. Beluhan and A. Ranogajec, "Chemical composition and non-volatile components of Croatian wild edible mushrooms," Food Chemistry, vol. 124, no. 3, pp. 1076-1082, 2011.

[8] M. Pardo-de-Santayana, J. Tardío, E. Blanco et al., "Traditional knowledge of wild edible plants used in the northwest of the Iberian Peninsula (Spain and Portugal): a comparative study," Journal of Ethnobiology and Ethnomedicine, vol. 3, no. 1, pp. 1-11, 2007.

[9] V. H. Heywood, Use and Potential of Wild Plants in Farm Households, Food \& Agriculture Organisation, Rome, Italy, 1999. 
[10] S. A. Shumsky, G. M. Hickey, B. Pelletier, and T. Johns, "Understanding the contribution of wild edible plants to rural social-ecological resilience in semi-arid Kenya," Ecology and Society, vol. 19, no. 4, 2014.

[11] G. Alemayehu, Z. Asfaw, and E. Kelbessa, "Plant diversity and ethnobotany in berehet district, north Shewa zone of Amhara region (Ethiopia) with emphasis on wild edible plants," Journal of Medicinal Plants Studies, vol. 3, no. 6, pp. 93-105, 2015.

[12] T. Berihun and E. Molla, "Study on the diversity and use of wild edible plants in Bullen District Northwest Ethiopia," Journal of Botany, vol. 10, 2017.

[13] E. Lulekal, Z. Asfaw, E. Kelbessa, and P. Van Damme, "Wild edible plants in Ethiopia: a review on their potential to combat food insecurity," Afrika Focus, vol. 24, no. 2, pp. 71-122, 2011.

[14] A. J. Afolayan and F. O. Jimoh, "Nutritional quality of some wild leafy vegetables in South Africa," International Journal of Food Sciences and Nutrition, vol. 60, no. 5, pp. 424-431, 2009.

[15] Z. Asfaw and M. Tadesse, "Prospects for sustainable use and development of wild food plants in Ethiopia," Economic Botany, vol. 55, no. 1, pp. 47-62, 2001.

[16] D. Ayele Amente, "Ethnobotanical survey of wild edible plants and their contribution for food security used by Gumuz people in Kamash Woreda; Benishangul Gumuz Regional State; Ethiopia," Journal of Food and Nutrition Sciences, vol. 5, no. 6, p. 217, 2017.

[17] K. Kehlenbeck, E. Asaah, and R. Jamnadass, "Diversity of indigenous fruit trees and their contribution to nutrition and livelihoods in sub-Saharan Africa: examples from Kenya and Cameroon," in Diversifying Food and Diets: Using Agricultural Biodiversity to Improve Nutrition and Health, pp. 257-269, Bioversity International, New Delhi, India, 2013.

[18] Y. Seyoum, D. Teketay, G. Shumi, and M. Wodafirash, "Edible wild fruit trees and shrubs and their socioeconomic significance in central Ethiopia," Ethnobotany Research and Applications, vol. 14, pp. 183-197, 2015.

[19] M. Tebkew, Y. Gebremariam, T. Mucheye, A. Alemu, A. Abich, and D. Fikir, "Uses of wild edible plants in Quara district, northwest Ethiopia: implication for forest management," Agriculture \& Food Security, vol. 7, no. 1, pp. 1-14, 2018.

[20] G. A. Getachew, Z. Asfaw, V. Singh, Z. Woldu, B.-F. Joseph Jojo, and S. Bhattacharya, "Dietary values of wild and semiwild edible plants in Southern Ethiopia," African Journal of Food, Agriculture, Nutrition and Development, vol. 13, no. 2, 2013.

[21] A. J. Simons and R. R. B. Leakey, "Tree domestication in tropical agroforestry," in New Vistas in Agroforestry, Advances in Agroforestry, P. K. R. Nair, M. R. Rao, and L. E. Buck, Eds., vol. 1, pp. 167-181, Springer, Dordrecht, The Netherlands, 2004.

[22] S. Franzel, H. Jaenicke, and W. Janssen, Choosing The Right Trees: Setting Priorities For Multipurpose Tree Improvement, International Service for National Agricultural Research (ISNAR), Hague, The Netherlands, 1996.

[23] S. Padulosi, J. Thompson, and P. G. Rudebjer, Fighting Poverty, Hunger and Malnutrition with Neglected and Underutilized Species: Needs, Challenges and the Way Forward, Bioversity International, New Delhi, India, 2013.

[24] M. Ashagre, Z. Asfaw, and E. Kelbessa, "Ethnobotanical study of wild edible plants in Burji District, Segan area zone of southern nations, nationalities and peoples region (SNNPR), Ethiopia," Journal of Ethnobiology and Ethnomedicine, vol. 12, no. 1, pp. 32-15, 2016.
[25] B. O. Muok, "Potentials and utilization of indigenous fruit trees for food and nutrition security in East Africa," Global Advanced Research Journal of Agricultural Science, vol. 8, no. 2, pp. 40-49, 2019.

[26] K. Balemie and F. Kebebew, "Ethnobotanical study of wild edible plants in Derashe and Kucha districts, South Ethiopia," Journal of Ethnobiology and Ethnomedicine, vol. 2, no. 1, pp. 53-59, 2006.

[27] T. Teklehaymanot and M. Giday, "Ethnobotanical study of wild edible plants of Kara and Kwego semi-pastoralist people in lower Omo river valley, Debub Omo zone, SNNPR, Ethiopia," Journal of Ethnobiology and Ethnomedicine, vol. 6, no. 1, pp. 23-28, 2010.

[28] A. Nefzaoui, P. Inglese, and a. T. Belay, "Improved utilization of cactus pear for food, feed, soil and water conservation and other products in Africa," in Proceedings of the 2010 International Workshop, Mekelle, Ethiopia, 2010.

[29] E. Guyassa, A. J. Raj, K. Gidey, and A. Tadesse, "Domestication of indigenous fruit and fodder trees/shrubs in dryland agroforestry and its implication on food security," International Journal of Ecosystem, vol. 4, no. 2, pp. 83-88, 2014.

[30] A. Assegid and T. Abebe, "Wild edible trees and shrubs in the semi-arid lowlands of southern Ethiopia," Journal of Science and Development, vol. 1, no. 1, pp. 5-19, 2011.

[31] B. Kidane, L. J. G. Van der Maesen, T. Van Andel, Z. Asfaw, and M. S. M. Sosef, "Ethnobotany of wild and semi-wild edible fruit species used by Maale and Ari ethnic communities in southern Ethiopia," Ethnobotany Research and Applications, vol. 12, pp. 455-472, 2014.

[32] T. Bahru, Z. Asfaw, and S. Demissew, "Wild edible plants: sustainable use and management by indigenous communities in and the buffer area of Awash National Park, Ethiopia," Ethiopian Journal of Science, vol. 36, no. 2, pp. 93-108, 2013.

[33] M. Tebkew, Z. Asfaw, and S. Zewudie, "Underutilized wild edible plants in the Chilga District, northwestern Ethiopia: focus on wild woody plants," Agriculture \& Food Security, vol. 3, no. 1, pp. 1-16, 2014.

[34] A. Negash, G. Hruy, and T. Semere, "Potentials and constraints of under-utilized tree fruits and vegetables in Tigray, northern Ethiopia," Journal of the Drylands, vol. 7, no. 2, pp. 664-674, 2017.

[35] A. Getachew, K. Urga, and D. Dikasso, "Ethnobotanical study of edible wild plants in some selected districts of Ethiopia," Human Ecology, vol. 33, no. 1, pp. 83-118, 2005.

[36] B. Chikamai, O. Eyog-Matig, and M. Mbogga, Review and Appraisal on the Status of Indigenous Fruits in Eastern Africa, Ipgri-Saforgen, Rome, Italy, 2004.

[37] A. O. Omotayo and A. O. Aremu, "Underutilized African indigenous fruit trees and food-nutrition security: opportunities, challenges, and prospects," Food and Energy Security, vol. 9, no. 3, pp. 1-16, 2020.

[38] D. Teketay and A. Eshete, Status of Indigenous Fruits in Ethiopia. Review and Appraisal on the Status of Indigenous Fruits in Eastern Africa, Afrena/Forenessa, Nairobi, Kenya, 2004.

[39] M. Sardeshpande and C. Shackleton, "Wild edible fruits: a systematic review of an under-researched multifunctional NTFP (non-timber forest product)," Forests, vol. 10, no. 6, p. 467, 2019.

[40] R. O. Awodoyin, O. S. Olubode, J. U. Ogbu, R. B. Balogun, J. U. Nwawuisi, and K. O. Orji, "Indigenous fruit trees of tropical Africa: status, opportunity for development and biodiversity management," Agricultural Sciences, vol. 6, no. 1, pp. 31-41, 2015. 
[41] P. Gepts, "Domestication of plants," Encyclopedia of Agriculture and Food Systems, Elsevier, Amsterdam, Netherlands, pp. 474-486, 2014.

[42] F. K. Akinnifesi, G. Sileshi, O. C. Ajayi et al., "Accelerated domestication and commercialization of indigenous fruit and nut trees to enhance better livelihoods in the tropics: lessons and way forward," in Indigenous Fruit Trees in the Tropics: Domestication, Utilization and Commercialization, pp. 392427, CABI International, Nairobi, Kenya, 2008.

[43] K. Kehlenbeck, M. Wiehle, and A. Sennhenn, "Exotic and indigenous fruit tree diversity on farm and the conservation of tree genetic resources: case studies from sub-Saharan Africa," in Tropical Fruit Tree Diversity, pp. 140-149, Routledge, Oxfordshire, UK, 2016.

[44] R. R. B. Leakey and E. K. Asaah, "Underutilised species as the backbone of multifunctional agriculture-the next wave of crop domestication," ISHS Acta Horticulturae: II International Symposium on Underutilized Plant Species: Crops for the Future-Beyond Food, vol. 979, pp. 293-310, 2011.

[45] A. Kalinganire, J. C. Weber, A. Uwamariya, and B. Kone, "Improving rural livelihoods through domestication of indigenous fruit trees in the parklands of the Sahel," in Indigenous Fruit Trees in the Tropics: Domestication, Utilization and Commercialization, vol. 10, pp. 186-203, CABI, Wallingford, UK, 2007.

[46] R. Cemansky, "Africa's indigenous fruit trees: a blessing in decline," Environmental Health Perspectives, vol. 123, no. 12, pp. A291-A296, 2015.

[47] M. Fentahun and H. Hager, "Integration of indigenous wild woody perennial edible fruit bearing species in the agricultural landscapes of Amhara region, Ethiopia," Agroforestry Systems, vol. 78, no. 1, pp. 79-95, 2010.

[48] M. Sundriyal and R. C. Sundriyal, "Underutilized edible plants of the Sikkim Himalaya: need for domestication," Current Science, vol. 85, no. 6, pp. 731-736, 2003.

[49] R. H. Jamnadass, I. K. Dawson, S. Franzel et al., "Improving livelihoods and nutrition in sub-Saharan Africa through the promotion of indigenous and exotic fruit production in smallholders' agroforestry systems: a review," International Forestry Review, vol. 13, no. 3, pp. 338-354, 2011.

[50] E. O. A. E. P. Mangaoang, "Preferred native tree species for smallholder forestry in Leyte," Annals of Tropical Research, vol. 25 , no. 1 , pp. 25-30, 2003.

[51] G. Mulugeta and M. Admassu, "Woody species diversity and their preferences on farmers' land holding," Journal of Natural Sciences Research, vol. 4, no. 9, pp. 96-108, 2014.

[52] E. Glover, "Local knowledge and tree species preference for land rehabilitation in Kenya," International Journal of Social Forestry, vol. 5, no. 1, pp. 57-83, 2012.

[53] A. D. Dirres, "Collection and identification of wild fruits tree/ shrub species in Amhara region, Ethiopia," Journal of Natural Sciences Research, vol. 6, no. 11, pp. 26-31, 2016.

[54] D. H. Feyssa, J. T. Njoka, Z. Asfaw, and M. M. Nyangito, "Seasonal availability and consumption of wild edible plants in semiarid Ethiopia: implications to food security and climate change adaptation," Journal of Horticulture and Forestry, vol. 3, no. 5, pp. 138-149, 2011.

[55] A. S. Saied, J. Gebauer, K. Hammer, and A. Buerkert, "Ziziphus spina-christi (L.) Willd.: a multipurpose fruit tree," Genetic Resources and Crop Evolution, vol. 55, no. 7, pp. 929-937, 2008.

[56] C. A. Okia, J. G. Agea, J. M. Kimondo, R. A. A. Abohassan, J. Obua, and Z. Teklehaima, "Harvesting and processing of Balanites aegyptiaca leaves and fruits for local consumption by rural communities in Uganda," Journal of Food Technology, vol. 9, no. 2, pp. 83-90, 2011.

[57] A. P. P. S. Fatima, P. Agarwal, R. Irchhaiya, S. Alok, and A. Verma, "Treatment of various diseases by Carissa spinarum L.: a promising shrub," International Journal of Pharmaceutical Sciences and Research, vol. 4, no. 7, pp. 2489-2495, 2013.

[58] J. Okello, J. B. L. Okullo, G. Eilu, P. Nyeko, and J. Obua, "Morphological variations in Tamarindus indica LINN. Fruits and seed traits in the different agroecological zones of Uganda," International Journal of Ecology, vol. 2018, Article ID 8469156, 12 pages, 2018.

[59] P. M. Mapongmetsem, G. Fawa, J. B. Noubissie-Tchiagam, B. A. Nkongmeneck, S. H. Biaou, and R. Bellefontaine, "Vegetative propagation of Vitex doniana Sweet from root segments cuttings," Bois et Forets des Tropiques, vol. 327, pp. 29-37, 2016.

[60] T. Diress, M. Balehgn, K. Gebrehiwot, M. Haile, G. Gebresamuel, and E. Aynekulu, The Role of Garsa (Dobera Glabra) for Household Food Security at Times of Food Shortage In Aba'ala Wereda, North Afar: Ecological Adaptation and Socio-Economic Value: A Study from Ethiopia, DCG, Oslo, Norway, 2007.

[61] C. M. Shackleton, A. E. Assogbadjo, and B. Sinsin, "Local knowledge on the uses, habitat, and change in abundance of multipurpose mimusops species in Benin," Economic Botany, vol. 71, no. 2, pp. 105-122, 2017.

[62] K. Mamo, H. Hulten, and B. Girma, "Vegetative propagation of juvenile leafy stem cuttings of Prunus africana (Hook. f.) Kalkm and Syzygium guineense (Willd.) DC," International Journal of Botany, vol. 9, no. 1, pp. 30-36, 2013.

[63] P. Gibbert, M. S. F. V. C. Cruz, A. C. P. Ristau, F. Villa, and M. d. M. Malavasi, "Physiological potential of seeds of Dovyalis abyssinica warb under different light quality," Journal of Experimental Agriculture International, vol. 26, no. 1, pp. 1-5, 2018.

[64] R. R. B. Leakey and F. K. Akinnifesi, "Towards a domestication strategy for indigenous fruit trees in the tropics," in Indigenous Fruit Trees in the Tropics: Domestication, Utilization and Commercialization, pp. 28-49, CAB International, Wallingford, UK, 2008.

[65] R. R. Leakey, J. C. Weber, T. Page et al., "Tree domestication in agroforestry: progress in the second decade (2003-2012)," in Agroforestry-The Future of Global Land Use, P. Nair and D. Garrity, Eds., vol. 9Dordrecht, The Netherlands, Springer, 2012.

[66] K. Dedefo, A. Derero, Y. Tesfaye, and J. Muriuki, "Tree nursery and seed procurement characteristics influence on seedling quality in Oromia, Ethiopia," Forests, Trees and Livelihoods, vol. 26, no. 2, pp. 96-110, 2017.

[67] T. Belay, M. Gebreselassie, and T. Abadi, "Description of cactus pear (opuntia ficus-indica (1.) mill.) cultivars from Tigray, northern Ethiopia. Mekelle, Tigray, Ethiopia," Tigray Agricultural Research Institute, Mekelle, Tigray, Ethiopia, 2011.

[68] B. Million and B. Leykun, "State of forest genetic resources in Ethiopia," in The Sub-regional Workshop FAO/IPGRI/ICRAF on the Conservation, Management, Sustainable Utilization and Enhancement of Forest Genetic Resources in Sahelian and North-Sudanian AfricaFAO, Rome, Italy, 2001.

[69] H. Jaenicke and J. Beniest, "Vegetative tree propagation in agroforestry: training guidelines and references," International Forestry Review, vol. 5, no. 2, 2003. 
[70] E. E. Goldschmidt, "The evolution of fruit tree productivity: a review," Economic Botany, vol. 67, no. 1, pp. 51-62, 2013.

[71] F. Taylor, S. M. Mateke, and K. J. Butterworth, A Holistic Approach to the Domestication and Commercialization of Non-timber Forest Products, Non Wood Forest Products (FAO), Rome, Italy, 1996.

[72] K. Schreckenberg, A. Awono, A. Degrande, C. Mbosso, O. Ndoye, and Z. Tchoundjeu, "Domesticating indigenous fruit trees as a contribution to poverty reduction," Forests, Trees and Livelihoods, vol. 16, no. 1, pp. 35-51, 2006.

[73] E. J. Bradbury, A. Duputié, M. Delêtre et al., "Geographic differences in patterns of genetic differentiation among bitter and sweet manioc (Manihot esculenta subsp. esculenta; Euphorbiaceae)," American Journal of Botany, vol. 100, no. 5, pp. 857-866, 2013. 